\title{
ARTICLE \\ Determinants of Small Business Owner Loan
}

\section{Jiameng Ma*}

School of Management, Shanghai University, Shanghai, 200444, China

\begin{tabular}{|c|c|}
\hline ARTICLE INFO & ABSTRACT \\
\hline Article history & \multirow{10}{*}{$\begin{array}{l}\text { Shareholders and debtholders have diverging objectives. Shareholders } \\
\text { are residual claimants whereas debtholders are fixed claimants to firm's } \\
\text { assets. In leveraged firms, shareholders may increase the value of their } \\
\text { claims at the expense of debtholders. The presence of shareholders be- } \\
\text { ing debtholders is a smart interest alignment, providing a solution to } \\
\text { shareholder-debtholder conflicts. This paper focuses on small businesses, } \\
\text { which play an important role in the United States economy but are gener- } \\
\text { ally neglected by academia. Utilizing National Survey of Small Business } \\
\text { Finance (NSSBF) data, this paper shows that firms with higher agency } \\
\text { cost of debt are more likely to issue owner loan. The incidence of small } \\
\text { business owner loan is positively associated with external lending diff- } \\
\text { culty, low shareholder agency cost and firm valuation difficulty. }\end{array}$} \\
\hline Received: 7 August 2019 & \\
\hline Revised. 12 August 2019 & \\
\hline & \\
\hline Accepted: 24 October 2019 & \\
\hline Published Online: 31 October 2019 & \\
\hline Keywords: & \\
\hline National Survey of Small Business Finance & \\
\hline$(\mathrm{NSSBF})$ & \\
\hline Shareholders & \\
\hline
\end{tabular}

Debtholders

\section{Introduction}

$\mathrm{O}$ bjectives of stockholders and debtholders diverge in terms of payoff maximization. The divergence stems from the difference in payoff structures where stockholders are residual claimants while debtholders are fixed claimants to firm's assets. The divergence can lead to conflict of interests between stockholders and debtholders when stockholders (or managers who act on behalf of stockholders) maximize stockholder wealth instead of firm value. Having expected that, debtholders may charge a higher price in offering debt financing. (Jensen and Meckling 1976, Myers 1977, Smith and Warner $\left.1979^{[1-3]}\right)$

An intuitive way to reduce cost of debt is the interest alignment between stockholder and debtholder. And the best alignment of interest is letting the two parties to be the same person. Existing inside debt literatures have already showed that when managers, on behalf of stockholders, hold company debt in the form of CEO pension and deferred compensation (compensations with debt properties), the company enjoys lower cost of debt (Jensen and Meckling 1976, Chen, Dou and Wang 2010, Wang, Xie, and Xin 2010, Edmans and Liu 2011, and Kabir, Li and Veld-Merkoulova $2013^{[1,4,5,6,7]}$ ).

Most literatures apply an indirect inside debt proxy of management compensation given the assumption that managers are the agents of stockholders. This paper is different first in the inside debt measurement (contribution one). Direct proxy of owner loan is utilized to investigate

\footnotetext{
*Corresponding Author:

Jiameng Ma,

Born in 1989, female, Shanghainese, assistant professor with area in financial management, School of Management, Shanghai University;

Correspondence address: School of Management, Shanghai University, No. 99 Shangda Road, Baoshan District, Shanghai, 200444, China;

E-mail: majiameng8918@163.com.
} 
the effects of stockholder-debtholder interest alignment in a more accurate way. Secondly, different from previous studies which lay emphasis only on large publicly traded firms, this study employs the setting of privately held small businesses which play an important role in the United States economy but are generally neglected by academia (contribution two).

The U.S. 1993 National Survey of Small Business Finance (NSSBF), one of the most extensive data sets available on small businesses, incorporates owner loan information__ direct measurement of shareholder debt holding. This new direct proxy and the new small business setting are important as they offer more accurate testing ground of beneficiaries and benefits of shareholders being debtholders for those sprouting firms which are influential not only in terms of great GDP and employment contribution but also in terms of the possibility that small businesses today may be market giants tomorrow.

Using 1993 NSSBF data set, this paper follows the findings of prior literatures that inside debt helps reduce agency cost of debt, and based on this argument the paper hypothesizes that for small businesses firms with higher agency cost of debt are more likely to issue owner loan.

Vast literatures have documented that high cost of debt are positively correlated with great difficulty of lending externally, low shareholder agency cost, and great firm valuation difficulty (Jensen and Meckling 1976, Sengupta 1998, Sundaram and Yermack 2007, Wittenberg-Moerman 2008, and Edmans and Liu 2010 $0^{[1,6,7,8,9,10]}$ ). Linking the literatures, this study proposes the following three hypotheses. First, firms with difficulty lending externally will turn to internal owner loan. Having difficulty obtaining external funding implies high agency cost of debt. And owner loan is a good signal of owner confidence in the firm and reduce the agency cost of debt. Second, firms with low shareholder agency cost will issue owner loan because external debtholders ask too high a price to protect themselves when interests of managers and shareholders are so aligned. Agency cost of debt derives from the conflict of interests between shareholders and debtholders to begin with. In modern corporations where managers are the agents of shareholders, there also exits shareholder agency cost because managers may not act in the best interests of shareholders. Therefore, shareholder-debtholder conflict of interests is to some extents manager-debtholder conflict of interests, which is negatively associated with shareholder agency cost. In low shareholder agency cost case, interests of managers are pretty much aligned with those of shareholders who may harm debtholders' wealth, so manager decisions are also very likely to harm debtholders' wealth and thus cause high agency cost of debt. And third, firms not able to be valued by external debtholders will refer to owner loan since external debtholders ask too high a price to protect themselves in case of low borrower transparency. The focus of the following empirical tests is to disentangle the above three hypotheses.

NSSBF small business data provides a detailed documentation of firm and owner characteristics, balance sheet and income statement information, and all sources of financial services used by the firm and recent capital injection. The survey is not an equal-probability sample design, so weights are included for the estimation of population statistics. SURVEYMEANS procedure is conducted to get the descriptive statistics which illustrate small businesses characteristics. On average small businesses are small in size, simple in business, high in leverage and low in shareholder agency cost.

The rest of the paper is organized as follows. Section 2 reviews related literature and develops hypotheses. Section 3 describes data and variables and discusses univariate results. Section 4 presents main regression results.

\section{Literature Review and Hypothesis Devel- opment}

\subsection{Literature}

Stockholders and debtholders have diverging objectives. As has been pointed out in the seminal work of Jensen and Meckling (1976) ${ }^{[1]}$, the divergence, which leads to stockholder-debtholder conflicts, arises from the fundamentally different payoff structures of stock and debt instruments. Debtholders are fixed claimants whereas stockholders are residual claimants to firm's assets. In leveraged firms, stockholders may increase the value of their claims at the expense of debtholders mainly in four ways: asset substitution or risk shifting, underinvestment, claim dilution and dividend payment (Jensen and Meckling 1976, Myers 1977, Smith and Warner $1979^{[1-3]}$ ). Stockholders can extract wealth from debtholders through undertaking investments that are riskier than before the issue of the bond. By engaging in such projects, stockholders whose risk is limited to the equity invested win upside benefit of higher expected returns, while debtholders who have no extra gain on these bear downside cost of increased default risk (asset substitution or risk shifting problem). Mirror image of the above, underinvestment problem occurs when stockholders avoid investment proceeds accruing to debtholders by refusing to invest in low-risk projects whose returns may only be enough to cover debt interests. In addition, stockholders may do harm to current debtholders' wealth by further issuances of higher prioritized debt (claim dilution problem) and by increases of dividend payments not 
matched by likewise increases in external financing (dividend payment problem).

Given that managers are the agents acting on behalf of stockholders the principles, stockholder-debtholder conflicts are to some extents manager-debtholder conflicts. To alleviate the conflicts, theorists have proposed the solution of having the manager hold debt and equity at the same time so that his aligned interests with debtholder weaken the incentive to transfer wealth from debtholders to stockholders (Jensen and Meckling 1976, Edmans and Liu 2011). The inclusion of debt in management compensation is named in literature inside debt, which takes the form of CEO pension and deferred compensation. Kabir, Li and Veld-Merkoulova (2013) offer empirical results that an increase in defined benefit pensions, debt compensation, is associated with lower bond yield spread, while higher share holdings, equity compensation, lead to higher spreads. Chen, Dou and Wang (2010) and Wang, Xie, and Xin (2010) have similar findings that inside debt holding is negatively associated with restrictiveness of debt covenants and cost of debt. Other empirical works also demonstrate that debt-based compensation makes manager think more like a debtholder by taking less risk (Cassell, Huang, Sanchez, and Stuart 2012, Dasgupta, Lin, Yamada and Zhang $2013^{[11,12]}$ ), lowering dividend payout and retaining more money inside the firm (White $2012^{[13]}$ ).

Instead of studying manager -debtholder conflicts, Jiang, Li and Shao (2010) $)^{[14]}$ utilize a unique data source and conduct a direct study of stockholder-debtholder conflicts by providing an analysis of the effects of simultaneous holding of equity and debt by institutional investors (dual-holders). They show that when stockholders are debtholders, better incentive alignment results in lower agency cost of debt.

\subsection{Hypotheses}

As discussed above, interest alignment of stockholders and debtholders reduces stockholder-debtholder conflicts, and thus agency cost of debt. The interest alignment, simultaneous holding of equity and loan by small businesses owners, therefore, offers a unique setting to test several hypotheses regarding that firms with higher agency cost of debt are more likely to have owner loan.

In the theoretical framework of Edmans and Liu (2010), manager compensation with debt-like payoffs helps reduce agency cost of debt. High-leveraged firms, therefore, use more inside debt, which is supported by the listed firm empirical evidence of Sundaram and Yermack (2007) a positive association between CEO's debt-to-equity ratio and the firm's leverage. By the same token, small businesses with greater external funding difficulty, corre- spondingly higher agency cost of debt, are more likely to issue owner loan.

(1) H1: Ceteris paribus, small businesses with greater external funding difficulty are more likely to issue owner loan.

Agency cost of debt is also related to firm's shareholder agency cost. According to Jensen and Meckling (1976), agency cost of debt derives from the conflict of interests between shareholders and debtholders to begin with. In modern corporations where managers are the agents of shareholders, there also exits shareholder agency cost because managers may not act in the best interests of shareholders. Therefore, shareholder-debtholder conflict of interests is to some extents manager-debtholder conflict of interests, which is negatively associated with shareholder agency cost. In low shareholder agency cost case, interests of managers are pretty much aligned with those of shareholders who may harm debtholders' wealth, so manager decisions are also very likely to harm debtholders' wealth and thus cause high agency cost of debt. In high shareholder agency cost case, however, the story is the opposite. Applying to the cases of small business, this paper expects that firms with lower shareholder agency cost have higher agency cost of debt and therefore are more likely to have owner loan.

(2) H2: Ceteris paribus, small businesses with lower shareholder agency cost are more likely to issue owner loan.

And intuitively, the more external investors know about the firm the lower the cost of debt. Using the bid-ask spread on the firm's loans traded on the secondary loan market as a measure of information asymmetry, Wittenberg-Moerman (2008) argues that a lower bid-ask spread on a borrower's traded loans leads to a lower interest rate on the borrower's subsequently issued loans. Similarly, Sengupta (1998) gives empirical evidence that high disclosure quality ratings from financial analysts reduce effective interest cost of issuing debt. For small businesses a similar measurement of firm transparency is the difficulty level of firm valuation. The paper expects that more valuation difficulty small businesses have the more likely the small businesses are to have owner loan.

(3) H3: Ceteris paribus, small businesses with higher valuation difficulty are more likely to issue owner loan.

\section{Data, Variables and Descriptive Statistics}

\subsection{Data}

The data sample is drawn from the U.S. 1993 National Survey of Small Business Finance (NSSBF), one of the most extensive data sets available on small businesses 
(Allee, and Yohn, 2009, ${ }^{[15]}$ ). The survey was a stratified random design, conducted for the Board of Governors of the Federal Reserve System and the U.S. Small Business Administration. The target population is all for-profit, nonfinancial, nonfarm businesses that had fewer than 500 employees and were in operation as of year-end 1992. Before the survey, businesses were contacted to decide eligibility, verify addresses, and identify a contact person. About $60 \%$ sampled businesses were eligible. Each eligible business was invited to complete a computer-assisted telephone interview averaged 50 minutes in addition to an advance written sheet. About $50 \%$ responded. NSSBF does not use an equal-probability sample design, so weights are included for the estimation of population statistics. In addition to firm and owner characteristics, balance sheet and income statement information about the firm, NSSBF provides a detailed documentation of all sources of financial services used by the firm and recent capital injection as well (Codebook for 1993 National Survey of Small Business Finance (NSSBF)).

1993 NSSBF contains firms with four organization types of proprietorship, partnership, S-corporation, and corporation. For this paper 2209 observations of S-corporation and corporation were included to begin with. After deletion of publicly traded firms, 2180 observations are left. After deletion of errors that liabilities over assets is larger than one and that total loans amount is less than owner loan amount, 2120 observations are left. After deletion of firms with franchise, 2014 observations are left. After deletion of error that relation length of primary institution is larger than zero years but number of distinct lending sources is equal to zero, 1653 observations are left. After deletion of outliers, 1606 observations are left.

\subsection{Variables}

The main variable of interest is whether the firm has loans from owners. It is labeled "OWNERLOAN" representing the question "As of yearend of 1993 did the firm have any loans form stockholders?" OWNERLOAN is an indicator variable, which is equal to 1 if the firm has owner loan or 0 if not.

For hypothesis one, external funding difficulty is proxied by four detailed measurements_—_leverage excluding owner loan, credit market problem, whether a lending request has been turned down before and firm delinquency on business obligations. Leverage excluding owner loan (LEVERAGE) is calculated as sum of reported liabilities deducting principle amount of loans from owners over sum of reported assets. Assets, liabilities and principle amount of owner loans are all in millions. The measurement of credit market problem is from the survey question

Table 1. Descriptive Statistics

This table reports descriptive statistics of main variables. Definitions of the variables are given in section 3 part B. NSSBF does not use an equal-probability sample design, so weights are applied in the mean estimation.

\begin{tabular}{|c|c|c|c|c|c|c|c|c|c|c|c|c|c|}
\hline & Min & 25 th percentile & Median & 75th percentile & Max & Mean & Std Error & Mean & Std Error & Mean & Std Error & p-value & \\
\hline OWNERLOAN & 0 & 0 & 0 & 1 & 1 & 0.318 & 0.017 & \multicolumn{2}{|c|}{ OWNERLOAN $=1$} & \multicolumn{2}{|c|}{ OWNERLOAN $=0$} & & \\
\hline LEVERAGE & 0.000 & 0.295 & 0.522 & 0.799 & 2.795 & 0.603 & 0.018 & 0.636 & 0.035 & 0.588 & 0.020 & 0.237 & \\
\hline SERIOUS MKT PROB & 0 & 0 & 0 & 0 & 1 & 0.157 & 0.013 & 0.265 & 0.029 & 0.106 & 0.013 & $<0.0001$ & $* * *$ \\
\hline SOME MKT PROB & 0 & 0 & 0 & 1 & 1 & 0.243 & 0.015 & 0.291 & 0.029 & 0.220 & 0.018 & 0.036 & $* *$ \\
\hline EVER DENIED & 0 & 0 & 0 & 0 & 1 & 0.149 & 0.013 & 0.218 & 0.026 & 0.117 & 0.014 & 0.001 & $* * *$ \\
\hline DELINQUENT ONE & 0 & 0 & 0 & 0 & 1 & 0.023 & 0.005 & 0.027 & 0.011 & 0.021 & 0.006 & 0.620 & \\
\hline DELINQUENT TWO & 0 & 0 & 0 & 0 & 1 & 0.220 & 0.015 & 0.347 & 0.031 & 0.161 & 0.016 & $<0.0001$ & $* * *$ \\
\hline MANAGER & 0 & 0 & 1 & 1 & 1 & 0.791 & 0.014 & 0.828 & 0.022 & 0.774 & 0.018 & 0.061 & * \\
\hline FAMILY & 0 & 0 & 1 & 1 & 1 & 0.764 & 0.015 & 0.798 & 0.025 & 0.748 & 0.019 & 0.108 & \\
\hline FOUNDER & 0 & 0 & 1 & 1 & 1 & 0.725 & 0.016 & 0.728 & 0.027 & 0.724 & 0.019 & 0.889 & \\
\hline AREA OF SALES & 1 & 1 & 2 & 2 & 4 & 1.656 & 0.027 & 1.781 & 0.051 & 1.598 & 0.031 & 0.002 & *** \\
\hline SITES & 1 & 1 & 1 & 2 & 20 & 1.591 & 0.041 & 1.574 & 0.059 & 1.599 & 0.053 & 0.749 & \\
\hline EXPORT & 0 & 0 & 0 & 0 & 1 & 0.150 & 0.012 & 0.242 & 0.026 & 0.107 & 0.013 & $<0.0001$ & $* * *$ \\
\hline R\&D PERCENTAGE & 0.000 & 0.000 & 0.000 & 0.029 & 1.000 & 0.106 & 0.010 & 0.095 & 0.016 & 0.111 & 0.013 & 0.452 & \\
\hline FINANCIAL STATEMENT & 0 & 0 & 0 & 1 & 1 & 0.186 & 0.013 & 0.195 & 0.023 & 0.182 & 0.016 & 0.622 & \\
\hline ASSETS & 0.002 & 0.190 & 0.782 & 2.800 & 79.589 & 0.909 & 0.042 & 0.933 & 0.068 & 0.897 & 0.053 & 0.674 & \\
\hline AGE & 0 & 0 & 0 & 0 & 1 & 0.179 & 0.014 & 0.171 & 0.024 & 0.182 & 0.017 & 0.709 & \\
\hline ROA & -3.514 & 0.000 & 0.093 & 0.351 & 8.167 & 0.348 & 0.051 & 0.123 & 0.058 & 0.453 & 0.068 & 0.000 & $* * *$ \\
\hline CCORP & 0 & 0 & 1 & 1 & 1 & 0.622 & 0.018 & 0.631 & 0.030 & 0.617 & 0.022 & 0.706 & \\
\hline
\end{tabular}


"How much of a problem were credit market conditions to the firm during the past 12 months?" Responding firms may choose from "serious problem", "somewhat of a problem" and "not a problem at all". Two indicator variables are created for the three levels of credit market problems. SERIOUS MKT PROB is equal to 1 if the firm answers with choice "serious problem" or 0 if not. SOME MKT PROB is equal to 1 if the firm answers with choice "somewhat of a problem" or 0 if not. The proxy whether a lending request has been turned down before originates from the survey question "During the last three years, has any particular lender or creditor turned down a request for credit from your firm?" EVER DENIED is an indicator variable which is equal to 1 if the firm responds yes to the question or 0 if not. Finally, firm delinquency on business obligations measurement is derived from the survey question "Within the past three years, on how many different obligations has the firm been 60 or more days delinquent?" Responding firms may choose from the four choices of "none", "1", "2", and "3 or more". Two indicator variables are created for this measurement. DELINQUENT ONE is equal to 1 if the firm responds with delinquency on one business obligation or 0 if not. DELINQUENT TWO is equal to 1 if the firm responds with delinquency on two or more business obligations or 0 if not.

For hypothesis two, shareholder agency cost is measured by three proxies_— whether the firm is managed by the owner, whether the firm is managed by a single family, and whether the firm is managed by the founder. MANAGER is an indicator variable following the survey question "Who is responsible for day-to-day management of the firm?" MANAGER is equal to 1 if the firm answers "owner" or 0 otherwise. FAMILY is an indicator variable originating from the survey question "Is more than $50 \%$ of the firm owned by a single family?" FAMILY is equal to 1 if the firm answers "yes" or 0 otherwise. FOUNDER is an indicator variable coming from the survey question "Was this business founded by the current owner or was an existing business purchased, inherited, or acquired as a gift?" FOUNDER is equal to 1 if the firm answers "founded by current owners" or 0 otherwise.

For hypothesis three, firm valuation difficulty is measured from 5 perspectives__area of sales, sites, whether the firm has export, percentage of R\&D employees and whether the firm has financial statements. AREA OF SALES follows the survey question "Where does the firm primarily sell or deliver its products?" It is equal to 1 if the firm sells or delivers its products in the same area of the firm's main office, equal to 2 if the sale or delivery is within the geographic region, equal to 3 if throughout the nation and equal to 4 if outside the United States. The SITES is a continuous variable measuring "at how many different sites the firm has offices, plants, or stores, including the main office". EXPORT is an indicator variable from the survey question "Does the firm export outside the United States?" EXPORT is equal to 1 if the answer is "yes" or 0 otherwise. Percentage of R\&D employees (R\&D PERCENTAGE) is calculated as 1993 average number of paid employees engaged in research and development activities over 1993 total number of employee hired. Both employee numbers include full-time and parttime employee numbers. The proxy whether the firm has financial statements is an indicator variable FINANCIAL STATEMENT equal to 1 if the firm has accounting records including financial statements, accounting or audit records and accounting software or 0 otherwise.

For control variables, assets, firm age, ROA, whether the firm is a corporation and industry fixed effects are included. The ASSETS is the sum of reported assets in millions. AGE is an indicator variable equal to 1 if the firm is less than or equal to five years old or 0 otherwise. ROA is a continuous variable calculated as total net profit over sum of reported assets. CCORP is an indicator variable equal to 1 if the firm is a corporation or 0 if the firm is an S-corporation (Ang, Cole, Lin, 2000; James, and Wier, 1990; Petersen, and Rajan, 1994, 1995, $2002^{[16-20]}$ ). Eight industry indicator variables are created for nine different industries- construction \& mining, primary manufacturing, other manufacturing, transportation, wholesale trade, retail trade, insurance $\&$ real estate, business services and professional services.

For goodness of the data, ROA is winsorized at both 1 percent and 99 percent, and LEVERAGE, SITES, and R\&D PERCENTAGE at 99 percent.

\section{Regression Results}

Results in Panel A of Table 2 offer evidence supporting H1. OWNERLOAN is significantly related to EXTERNAL FUNDING, principle component of detailed external financing difficulty variables LEVERAGE, SERIOUS MKT PROB, SOME MKT PROB, EVER DENIED, DELINQUENT ONE, and DELINQUENT TWO. On average, one point increase in external funding difficulty will lead to $22 \%$ increase in probability of having owner loan. Detailed analysis shows if a firm regards credit market conditions as some problems it is $11 \%$ more likely to have owner loan than firms that do not consider credit market conditions as problems at all and if a firm regards credit market conditions as serious problems it is $26 \%$ more likely to have owner loan than firms that do not consider credit market conditions as problems at all. Additionally, 
Table 2. Determinants of Small Business Owner Loan

EXTERNAL FUNDING is principle component of detailed external financing difficulty variables LEVERAGE, SERIOUS MKT PROB, SOME MKT PROB, EVER DENIED, DELINQUENT ONE, and DELINQUENT TWO. AGENCY COST is principle component of detailed low shareholder agency cost variables MANAGER, FAMILY, and FOUNDER. FIRM VALUATION is principle component of detailed firm valuation difficulty variables AREA OF SALES, SITES, EXPORT, R\&D PERCENTAGE and FINANCIAL STATEMENT. All other variables are defined in section 3 part B. The dependent variable is OWNERLOAN. NSSBF does not use an equal-probability sample design, so survey logit regressions are applied in each panel. Industry fixed effects are included but not reported.

Panel A: External financing availability

\begin{tabular}{|c|c|c|c|c|c|c|c|c|c|c|}
\hline & Est & $\mathrm{dy} / \mathrm{dx}$ & $\mathrm{t}$-stat & $\mathrm{p}$ - value & & Est & $\mathrm{dy} / \mathrm{dx}$ & $\mathrm{t}$-stat & $\mathrm{p}$ - value & \\
\hline EXTERNAL FUNDING & 1.038 & $21.73 \%$ & 6.25 & $<0.0001$ & $* * *$ & & & & & \\
\hline LEVERAGE & & & & & & 0.062 & $1.28 \%$ & 0.35 & 0.727 & \\
\hline SERIOUS MKT PROB & & & & & & 1.140 & $26.34 \%$ & 4.94 & $<0.0001$ & $* * *$ \\
\hline SOME MKT PROB & & & & & & 0.517 & $11.26 \%$ & 2.58 & 0.010 & $* * *$ \\
\hline EVER DENIED & & & & & & 0.194 & $4.15 \%$ & 0.77 & 0.439 & \\
\hline DELINQUENT ONE & & & & & & 0.252 & $5.49 \%$ & 0.50 & 0.616 & \\
\hline DELINQUENT TWO & & & & & & 0.659 & $14.59 \%$ & 3.26 & 0.001 & $* * *$ \\
\hline ASSETS & -0.013 & $-0.28 \%$ & -0.80 & 0.425 & & -0.016 & $-0.33 \%$ & -0.93 & 0.354 & \\
\hline AGE & -0.274 & $-5.52 \%$ & -1.24 & 0.217 & & -0.222 & $-4.48 \%$ & -1.00 & 0.318 & \\
\hline ROA & -0.165 & $-3.45 \%$ & -2.73 & 0.006 & $* * *$ & -0.178 & $-3.69 \%$ & -2.82 & 0.005 & $* * *$ \\
\hline CCORP & -0.013 & $-0.28 \%$ & -0.08 & 0.937 & & -0.019 & $-0.39 \%$ & -0.11 & 0.913 & \\
\hline $\mathrm{n}$ & 1606 & & & & & 1606 & & & & \\
\hline
\end{tabular}

Panel B: Low shareholder agency cost

\begin{tabular}{|c|c|c|c|c|c|c|c|c|c|c|}
\hline & Est & $\mathrm{dy} / \mathrm{dx}$ & $\mathrm{t}$-stat & $\mathrm{p}$ - value & & Est & $\mathrm{dy} / \mathrm{dx}$ & $\mathrm{t}$-stat & $\mathrm{p}$ - value & \\
\hline AGENCY COST & 0.431 & $9.12 \%$ & 2.39 & 0.017 & $* *$ & & & & & \\
\hline MANAGER & & & & & & 0.401 & $8.05 \%$ & 2.08 & 0.038 & $* *$ \\
\hline FAMILY & & & & & & 0.335 & $6.81 \%$ & 1.78 & 0.075 & $*$ \\
\hline FOUNDER & & & & & & 0.125 & $2.60 \%$ & 0.71 & 0.480 & \\
\hline ASSETS & -0.024 & $-0.50 \%$ & -1.29 & 0.196 & & -0.017 & $-0.36 \%$ & -0.96 & 0.337 & \\
\hline AGE & -0.098 & $-2.04 \%$ & -0.47 & 0.636 & & -0.086 & $-1.79 \%$ & -0.41 & 0.679 & \\
\hline ROA & -0.204 & $-4.32 \%$ & -3.28 & 0.001 & $* * *$ & -0.206 & $-4.36 \%$ & -3.33 & 0.001 & $* * *$ \\
\hline CCORP & -0.033 & $-0.69 \%$ & -0.20 & 0.843 & & -0.027 & $-0.58 \%$ & -0.16 & 0.869 & \\
\hline $\mathrm{n}$ & 1606 & & & & & 1606 & & & & \\
\hline
\end{tabular}

Panel C: Firm valuation difficulty

\begin{tabular}{|c|c|c|c|c|c|c|c|c|c|c|}
\hline & Est & dy/dx & $\mathrm{t}$-stat & $\mathrm{p}$ - value & & Est & dy/dx & t-stat & $\mathrm{p}$ - value & \\
\hline FIRM VALUATION & 0.338 & $7.15 \%$ & 2.88 & 0.004 & $* * *$ & & & & & \\
\hline AREA OF SALES & & & & & & 0.113 & $2.39 \%$ & 0.91 & 0.361 & \\
\hline SITES & & & & & & -0.006 & $-0.12 \%$ & -0.18 & 0.858 & \\
\hline EXPORT & & & & & & 0.691 & $15.74 \%$ & 2.83 & 0.005 & $* * *$ \\
\hline R\&D PERCENTAGE & & & & & & -0.254 & $-5.37 \%$ & -0.67 & 0.505 & \\
\hline FINANCIAL STATEMENT & & & & & & -0.037 & $-0.77 \%$ & -0.19 & 0.852 & \\
\hline ASSETS & -0.044 & $-0.92 \%$ & -2.11 & 0.035 & $* *$ & -0.041 & $-0.86 \%$ & -1.87 & 0.062 & $*$ \\
\hline AGE & -0.149 & $-3.09 \%$ & -0.72 & 0.474 & & -0.110 & $-2.30 \%$ & -0.51 & 0.609 & \\
\hline ROA & -0.197 & $-4.17 \%$ & -3.11 & 0.002 & $* * *$ & -0.203 & $-4.28 \%$ & -3.09 & 0.002 & $* * *$ \\
\hline CCORP & -0.022 & $-0.46 \%$ & -0.13 & 0.895 & & -0.036 & $-0.77 \%$ & -0.22 & 0.827 & \\
\hline $\mathrm{n}$ & 1599 & & & & & 1599 & & & & \\
\hline
\end{tabular}

Panel D: Multi-determinants

\begin{tabular}{|c|c|c|c|c|c|}
\hline & Est & dy/dx & t-stat & p-value & \\
\hline EXTERNAL FUNDING & 1.045 & $21.71 \%$ & 6.37 & $<0.0001$ & $* * *$ \\
\hline AGENCY COST & 0.563 & $11.69 \%$ & 2.95 & 0.003 & $* * *$ \\
\hline FIRM VALUATION & 0.371 & $7.71 \%$ & 3.08 & 0.002 & $* * *$ \\
\hline ASSETS & -0.029 & $-0.60 \%$ & -1.46 & 0.144 & \\
\hline AGE & -0.311 & $-6.18 \%$ & -1.43 & 0.152 & \\
\hline ROA & -0.173 & $-3.59 \%$ & -2.78 & 0.005 & $* * *$ \\
\hline CCORP & 0.010 & $0.20 \%$ & 0.06 & 0.955 & \\
\hline $\mathrm{n}$ & 1599 & & & & \\
\hline
\end{tabular}


if a firm has been delinquent on only one business obligation, it does not have significant difference with firms that have never been delinquent on any obligation in terms of owner loan likelihood. However, if a firm has been delinquent on two or more than two business obligations, it is $15 \%$ more likely to have owner loan than firms that have never been delinquent on any obligation.

Panel B of Table 2 proves that $\mathrm{H} 2$ holds. OWNERLOAN is positively associated with AGENCY COST, principle component of detailed shareholder agency cost variables MANAGER, FAMILY, and FOUNDER. One point less shareholder agency cost will result in 9\% increase in probability of issuance of owner loan. Further investigation suggests that owner managed firms are $8 \%$ more likely to have owner loan than non-owner managed firms and family owned firms are 7\% more likely to have owner loan than non-family owned firms, whereas whether the firm is owned by founder does not have significant effect on OWNERLOAN.

Panel C of Table 2 confirms H3 holds. There is significantly positive association between OWNERLOAN and FIRM VALUATION, principle component of detailed firm valuation difficulty variables AREA OF SALES, SITES, EXPORT, R\&D PERCENTAGE and FINANCIAL STATEMENT. One point increase in firm valuation difficulty will cause $7 \%$ increase of owner loan probability. More specifically, information asymmetry from export activity will make firms $16 \%$ more likely to give owner loan than non-export firms in order to reduce cost of debt.

Panel D of Table 2 discusses the three hypotheses comprehensively. Survey logit regression argues high difficulty of lending externally (H1), low shareholder agency cost (H2) and high difficulty of firm valuation (H3) are significant determinants of owner loan issuance. Given the existence of other two factors, one point increase in external financing difficulty, decrease in shareholder agency cost, and increase in valuation difficulty will bring about $22 \%, 12 \%$, and $8 \%$ increase respectively in probability of having owner loan to reduce cost of debt.

Finally, it is worth pointing out that in all the above four panels except panel $\mathrm{C}$, the incidence of owner loan is not determined by the size of the firm measured by assets in book value nor by difference in tax treatment. The only control variable with significant coefficient is ROA, implying that firm profitability is also a determinant of giving owner loan or not. Given other factors all equal, high profitability firms may use retained earnings to finance investments while low profitability firms are 4\% more likely to have owner loan due to retained earnings insufficiency.

\section{References}

[1] Jensen, Michael and William Meckling, 1976, Theory of the firm: Managerial behavior, agency costs and ownership structure, Journal of Financial Economics 3, 305-360.

[2] Myers, Stuart, 1977, The determinants of corporate borrowing, Journal of Financial Economics 5, 147175.

[3] Smith, Clifford, and Jerold Warner, 1979, On financial contracting: An analysis of bond covenants, Journal of Financial Economics 7, 117-161.

[4] Chen, Feng, Yiwei Dou, and Xin Wang, 2010, Executive inside debt holdings and creditors' demand for pricing and non-pricing protections, Working paper.

[5] Wang, Cong, Fei Xie, Xiangang Xin, 2010, Managerial ownership of debt and bank loan contracting, Working Paper.

[6] Edmans, Alex, and Qi Liu, 2011, Inside Debt, Review of Finance 15, 75-102.

[7] Kabir, Rezaul, Hao Li, and Yulia Veld-Merkoulova, 2013, Executive compensation and the cost of debt, Journal of Banking \& Finance 3, 2893-2907.

[8] Sengupta, Partha, 1998, Corporate disclosure quality and the cost of debt, The Accounting Review 73, 459-474.

[9] Sundaram, Rangarajan, and David Yermack, 2007, Pay me later: Inside debt and its role in managerial compensation, Journal of Finance 62, 1551-1588.

[10] Wittenberg-Moerman, Regina, 2008, The role of information asymmetry and financial reporting quality in debt trading: Evidence from the secondary loan market, Journal of Accounting and Economics 46, 240-260.

[11] Cassell, Cory, Shawn Huang, Juan Manuel Sanchez, and Michael Stuart, 2012, Seeking safety: The relation between CEO inside debt holdings and the riskiness of firm investment and financial policies, Journal of Financial Economics 103, 588-610.

[12] Dasgupta, Sudipto, Yupeng Lin, Takeshi Yamada, and Zilong Zhang, 2013, Employee inside debt and firm risk-taking: Evidence from employee deposit programs in Japan, Working paper.

[13] White, Reilly, 2012, Inside debt and firm dividend policy, Working paper.

[14] Jiang, Wei, Kai Li, and Pei Shao, 2010, When shareholders are creditors: Effects of the simultaneous holding of equity and debt by institutional investors, Review of Financial Studies 23, 3595-3637.

[15] Allee, Kristian, Teri Lombardi Yohn, 2009, The demand for financial statements in an unregulated environment: An examination of the production and 
use of financial statements by privately held small businesses, The Accounting Review 84, 1-25.

[16] Ang, James, Rebel Cole, James Wuh Lin, 2000, Agency costs and ownership structure, The Journal of Finance 55, 81-106.

[17] James, Christopher and Peggy Wier, 1990, Borrowing relationships, intermediation, and the cost of issuing public securities, Journal of Financial Economics 28, 149-171.

[18] Petersen, Mitchell, Raghuram Rajan, 1994, The ben- efits of lending relationships: Evidence from small business data, The Journal of Finance 49, 3-37.

[19] Petersen, Mitchell, Raghuram Rajan, 1995, The effect of credit market competition on lending relationships. The Quarterly Journal of Economics 110, 407443.

[20] Petersen, Mitchell, Raghuram Rajan, 2002, Does distance still matter? The information revolution in small business lending, The Journal of Finance 57, 2533-2570. 